\title{
A Critical Analysis of Sharankumar Limbale's Hindu: A Novel (2010)
}

\section{Priyanka Arora}

MPhil English Literature

Department of English

University of Delhi

New Delhi, India

priyankaa440@gmail.com

\section{Abstract}

A Critical Analysis of Sharankumar Limbale's Hindu: A Novel (2010) This paper critically analysis Sharankumar Limbale's Hindu: A Novel (2010). It is set in a small casteist village of Achalpur in Maharashtra and is translated from Marathi (2003) by Arun Prabha Mukherjee in 2010. Dalit literature has undergone a transformation in the twenty-first century and Sharankumar Limbale is an active participant in it. The paper, thus, traces this very trajectory along with providing a detailed analysis of the plethora of techniques Limbale employs to present a world of Dalits, which is not binary world but one where characters are grey and humane; where the path Dr. B. R. Ambedkar left for them to follow is not liberating enough; where the struggle against casteism is as much internal as it is external; where the women and the lower class are doubly oppressed; and where the Dalit movement's trajectory is in question. This paper then addresses these themes and tries to comprehend what Limbale tries to project through his work.

Keywords- Dalit Literature, Gender, Caste, Dalit Aesthetics, Dalit Movement. 
The novel is set in Maharashtra and is translated from Marathi (2003) by Arun Prabha Mukherjee in 2010. Maharashtra was the heartland of the beginning of Dalit uprising under the leadership of Jyotiba Phule and B. R. Ambedkar. Later with the rise of the Dalit Panther Movement, Maharashtra saw many prominent writers like Arjun Dangle, Namdeo Dhasal and Sharankumar Limbale. Dalit literature for Limbale is “...a lofty image of grief” (Towards an Aesthetic of Dalit Literature 30).

Mukherjee calls this novel as "an important document in the social history of contemporary India" (Mukherjee xiii). The novel is not a whodunit and it moves away from the genre of autobiography and memoirs. It presents to us a politically, socially and culturally laden work which “...challenges the claims of universality made by mainstream high caste writers and its critics by pointing out that they either ignore Dalits altogether or misrepresent them" (Mukherjee xv). This 'misrepresentation' or universalisation of the Dalits is what this paper will try to analyse through the study of Limbale's Hindu: A Novel. Limbale writes, "In those writers who have portrayed Dalits, there is compassion, but there are no images of Dalits with self-pride" (Towards an Aesthetic of Dalit Literature 27). Thus he questions a generalised narrative of Dalits by questioning the binary of upper caste versus lower caste which has made people turn a blind eye towards viewing caste from a multidimensional lens.

The figures before each chapter symbolise the predatory imagery; big fish after a smaller one, the 'Self' and the 'Other' depicted by two faces separated with a line, Hinduism in opposition to Dalits as depicted by a Trishul (symbol of Shaivism) and a face. The use of full names of all characters throughout the text is indicative of an objective distance that Limbale wants the readers to maintain. Along with this, to name is not to be afraid of one's identity.

The work is set in the village of Achalpur in Maharashtra which acts as a microcosm for the casteist society. The word achal is a Hindi word which means immovable. This 
foregrounds the caste and gender hierarchies that seems to be static or immovable no matter how strongly opposed. Limbale questions this immovableness of Caste and Gender through his work. It starts with a poem which clearly demarcates the difference between 'you' and an 'untouchable' along with sensitising the reader to the term, 'Hindu'. Limbale contrasts this with the sentences that follow which are filled with metaphors, symbols and chants of Buddhism. The "stupas of determination" (1) seem to be the only hope for these untouchables who are discriminated because they are a 'Hindu'. The title of the novel addresses two key aspects; one the 'Hindu' religion as being drenched in gender and caste hierarchies and also questioning if Dalits are Hindus? and the other fragment of the title, 'A Novel' reiterates the departure from depictions of the real lives of Dalits in forms of memoirs or autobiographies.

Quite early in the novel we hear of conversion. "Dalits now converted to Buddhism. They had thrown away the idols of the Hindu gods and goddesses onto the garbage. Some had buried them. Dalits were now following new faiths, new ways of worship" (5-6). Milind Kamble's wife "stealthily" worships the Hindu gods and goddesses. Milind too finds strength from the Hindu gods and goddesses while when he is confident, he bows before Ambedkar and Buddha figures thereby presenting their internal dilemma.

The naming of Bhimnagar is politicisation of the village that was socially abrogated or put in the peripheries. As nagar means town, it is a rejection of the framework of village which Ambedkar too found limiting and casteist. According to the Milind Kamble, "all homes should look alike" (13) reiterating the need for equality. But he contradicts himself when he goes with the twins, Gopichand and Manikchand, who belong to the upper caste or when he wants to gain power so that his words are heard and adhered to in the movement.

Tatya Kamble believes in conversion to Buddhism. He appeals to his fellowmen to convert on Dhamma Chakra Parivartan day. The chakra is indicative of the circle of life or here the circle of Casteism which will only break or rather change (Parivartan) through 
conversion according to Tatya. But it is difficult to align Limbale's stance with Tatya's ideology as "[complete] transformation is not possible until the economic slavery of the dalits is destroyed"(82). Thus the first chapter itself spells out Tatya Kamble's murder. An activist, his murder is presented to us through the two upper caste men's version of Tatya Kamble's hate speech towards Hinduism which led to his mob lynching. "It was the disfigured face of social terrorism" (12) for many. Casteist upper caste Hindus, Vishnu Pandit and Shankar Pujari suggest violent means to exterminate the Dalits and bribe the intelligentsia alongside keeping them away from political power and rights. In Limbale's work, the ideology of the Dalit as being meant to serve the upper caste Hindus is interpellated by many people belonging to different castes which makes caste an entangled web that seems almost impossible to untangle. The lecture by Dayanand Kinikar on "Dr. Babasaheb Ambedkar's role in religious conversion" attempts to untangle it by emphasising on the need for education, intellect and a change in the perspective of everyone with respect to looking at caste and Dalits.

But we see Muslims are smeared with gulaal or red colour by Hindutvite upper caste Hindus to present the religious superiority the upper caste Hindus feel. Similarly, when Kasbe Guruji teaches Ambedkar's lesson in school, the upper caste people led by Narendra Patil threaten him and tear off the pages in the textbook which tell the story of Ambedkar(35). The imitation of this violent act by students is a deliberate attempt by Limbale to address the vulnerability of children and their mouldable nature which is exploited by the casteist society. While Kasbe Guruji asks for a transfer, Godbole Guruji tries to pacify him by claiming that "[our] Hindu religion is a tolerant religion"(36) hence the need for 'Ghar Wapsi' but 'ghar' means home which stands for acceptance while this is a political move to convert back Dalits to Hinduism. The Cambridge definition of 'tolerance' states that it is to be "willing to accept behaviour and beliefs that are different from your own, although 
you might not agree with or approve of them". One needs to question the terminology employed by savarnas which in itself presents the inequality in terms of economic standing, power, political representation and dignity. The dependence of the Mahars on the village for earning their living makes them bound to caste as well. We see Mangesh Kamble, Sandeep Pholke and Dhiraj Pagare leave for Mumbai towards the end of the text while others employ cattle or work on their art to make themselves economically independent. The term dignity too is subjective and Limbale plays around it. Where being beaten up by 'chappals' for Sadanand Kamble results in his loss of dignity, murder of Tatya Kamble is celebrated as a martyrdom. Where Kabir Kamble's dancing in the procession in feminine attire is marked as pride of the culture of the Achalpur Dalits, the neutering of Milind Kamble into a eunuch at the end of the novel is because of his loss of dignity and self-respect.

'A Note on the Translation' makes the reader conscious of the movement of language and culture on both the sides across the porous border between the works and their translations. Thus it capsizes the flow of translation by referring to the English words that were used in the original work instead of narrating the experience of movement of language from Marathi to English.

Gopichand and Manikchand are "gharjamais"(6) of Bankat Seth and stay at their wives' maternal homes. Predator imagery is used for them and their names are always uttered together. They are twins thereby alluding to not individuals but a joint community or caste that thinks alike. They "treated others like servants"(7) which is indicative of their internalisation of caste hierarchy.

When they drag in a Dalit woman and rape her, she pleads, "I fall at your feet. Spare me" (20). This translation of falling at someone's feet lacks the cultural connotation that is attached to it. Falling at someone's feet is not just a gesture but also is laden with a person being stripped off their self respect and dignity thereby presenting the doubly oppressed Dalit 
women who have to let go of their self respect to maintain their 'honour' or the right to not get raped. Words like 'jaadu tona' are also used as they are. The clapping of the eunuch in the end lacks the societal connotations attached with it as it is a specific clap that forms a part of their identity.

We are told that "[nature] looked mysterious" (14) on the night of Tatya Kamble's death. The barking of the dogs, the accentuated darkness of the night are objective correlatives that Limbale employs in his writing as used in Indian literature.

The day Tatya is murdered, Milind says Gopichand and Manikchand 'got' him. They 'stuck' with him, 'never broke up' with him which seem to be positive attributes in a friendship. But gradually we are revealed that it is because of their own ulterior motives that they do not sever this relationship with the narrator. Milind Kamble is unreliable because he himself claims to be "the scum of hedonism and selfishness"(6) and thus his narrative too cannot be trusted.

While talking about the Dalits, Milind says, "They too have penises. Pockets. Bellies”(8). Milind's conflict portrays how movement is not comprised of hyperrevolutionised people who have clarity of what they are and how they want to bring about a reform. They too are humans who aspire to be treated like one, who too feel pleasure, pain, hunger and avarice. When Gopichand commends Dalit community about their unity, he is ironically talking to Milind, a Dalit man who does not report Tatya Kamble's murder because he lacks courage. Limbale lets us into Milind's psyche where he feels to be drinking liquor with the twins is an achievement while no Mahar can sit with savarnas and even drink water. The dilemma of being true to the movement and feeling a sense of achievement for moving upwards in the caste hierarchy gnaws the narrator from within. Limbale craftily presents the reader with the inherent disjointedness amongst the perceived 'unity' behind the Dalit movement. This is later resonated in Sadanand Kamble, brother of Tatya Kamble. According 
to Manikchand, "There must always be conflict in society"(23) which gives way to the difference between the 'Self' and the 'Other'. The readers need to question this binary and realise that the Dalit Movement too is politicised and appropriated by the powerful to maintain this binary as the Professor Rahul Bansode does by taking the dead body to the collectorate's office before the cremation ground to demand justice. The two twins too "play the game" by providing shelter to Sadanand Kamble and his family. The newspaper coverage they get because of one of their friends adds to their prestige in the society, as protectors of Dalits. This idea of being a 'saviour' reinstates the hierarchical stance which the Dalit Movement and Tatya himself were trying to adjudicate.

Thus "Many disagreements hide under the cover of unity. They get exposed as time goes on and our unity is fractured"(Rama Babar 74). The primary reason for this fracture is fear. The Jalsa provides a message that "[those] who get accustomed to living in slavery begin to fear freedom"(49). This fear is visible in Milind's inability to stand up for the movement and in Sadanand's continuing his job as a watchman of Gopichand and Manikchand even after becoming the sarpanch. Milind feels upset by the "cowardice of the crowd" (13) after the murder of Tatya Kamble. But he too feels fearful and does not stand against Rambhau Kavale. He says, "I was a parasitic plant attached to the movement"(21). He understands his shortcomings and the poem reads, "The scummiest, rottenest part of my body is my conscience" (22). There is a conflict of interest that holds back Dalits and their unity. Fear is also an important entity that cripples Dalits which is accentuated when the law is not executed properly. Fear also grips Sonali when she hides the truth about her husband murdering Tatya Kamble or Savita Kamble when she fears for her son's love for Sonali as violence often precedes the achievement of justice.

Tatya Kamble's murder by Prabhakar Kavale, the elder son of Rambhau Kavale is indicative of the ineffectiveness of Prevention of Atrocities against Scheduled Castes and 
Scheduled Tribes is ineffective in controlling atrocities against Dalits. Corruption and the nexus of businessmen, police and ministers is exposed by Limbale. He writes with sarcasm, "Our chest must swell with pride when we testify for these criminals. This must be the secret of our successful life"(69). Gopichand and Manikchand gradually increase this nexus by mediating between the upper caste people and Dalits to garner political support but they exploit Sadanand's name for their own material benefits. They hire people for a demonstration against the murder of Tatya Kamble which politicises the Dalit movement instead of offering a petition as supported by Rama Babar, Professor Rahul Bansode and Yaqub Sheikh. Prabhakar Kavale admits of his crime in front of Gopichand and Manikchand and asks for protection. His reason for murdering Tatya is that he "did not respect our charity"(17). The charity is indicative of the hierarchy which has been internalised and as Tatya does not adhere to it, he is exterminated from the fabric of society itself.

The official report submitted by Rambhau Kavale states "unknown miscreants"(53) that murdered Tatya Kamble. Jagannath Patil uses a fake certificate to get a job. Later, Surekha Mane forges a fake complaint against Narendra Patil on the pretext of sexual assault to assert her power over him. Thus we must not forget that official or factual documents are manipulated from both sides for their own benefit. Newspaper reports are reconstructed by Dalits themselves thereby promoting Neo-social realism.

Their murder of Tatya Kamble is plotted in the Mahadev temple. The Dalits' huts are burnt and a dead cow thrown in the house of Kabir Kamble. The accused are arrested and Vishnu Pandit says that "[if] a savarna had been murdered, they would have granted bail ten times now"(67). Rambhau Kavale is seen "working on buying off the judge"(64) where though the accused are not granted bail, in the end they are declared innocent. Thus Limbale leaves it to the readers to assess the transparency and justice of the court of law which is run 
by unbiased policemen as Limbale too held a position in the police department thereby letting in his personal bias.

"For the first time, people responsible for committing reckless atrocities against Dalits were behind bars. For the first time, those who refused to accept Dalits as human beings were made to feel that "everyone was equal before the law"'(34). The movement towards equality comes at the cost of disturbance of social order according to the Savarnas. They see the law favouring the Dalits. For them, they are a threat to the social order as Tatya refused to dance and perform and even ask for 'bidagi' or payment in return. The division of labour is disturbed according to the savarnas which makes them feel like stepchildren of the law. They feel the Dalits will eat their food and still oppose them. Jagannath Pandit obtains a job using a fake caste certificate. This is exposed by Sadashiv More, brother of Ranjana because Jagannath refuses to marry her after he gets this job.

Sadanand Kamble is discriminated against throughout the text. He is a watchman at the farmhouse of the twins who use him to win the elections and then manipulate the upper caste Hindus to vote for him as he would work for them. They ask for money under his name and let him touch their feet, claiming themselves to be 'king makers'. Primarily he is refused ration after his brother's death, he is not accepted as a Sarpanch, he is refused from hoisting the National Flag as he would 'pollute' it unless police arrives to administer the ceremony, at the ceremony as well he stands alone while all others are seen interacting with each other while finally his voice is conveyed to us through his manager thereby getting lost in his position of power but permanently distanced from the people of his village. Thus " [the] old social order was falling apart and a new one was emerging" (97) but it came with its own rules and restrictions. Savarnas too are a victim of it because their "deeply ingrained beliefs"(102) stifles them as well. Limbale tries to rupture this binary of the 'Self' and the 'Other' by using the Jalsa or tamasha. 
The folk tradition of tamasha started with Jyotiba Phule and in the novel it is started in Achalpur by Tatya Kamble's grandfather, expanded by his father and revolutionised as Ambedkari Jalsa by himself . It is celebrated by Limbale. It presents a narrative of swans that are caught by hunters disguised as ascetics. The pet partridges are traitors who "become pets"(49) for their personal gain. It ends with a warning that "...the hunters have changed their garb, language and weapons. Now we need to be more vigilant" (45). This metaphorical rendering of swans as Dalits who are caught in the web of Casteism by casteist people who adorn the garb of liberalised and modernised Hindus. For Limbale, hunters belong to the upper caste while pet partridges are men like Sadanand or Milind who cause divisions within the Dalit community. These hunters and their pets might be divided in their caste identity but are united in their perspective towards it. The Jalsa then is a tradition that connects the people and is later politicised when Professor Rahul Bansode and his friends use it to mobilise people to vote in his favour. But tamasha is also viewed by Sonali from her rooftop thereby bridging the invisible yet existing boundaries. She is a significant character who links the two worlds, the upper caste life inside the bara and the life of the Dalits outside of it, as viewed from her rooftop.

Spaces then act as vital components to analyse this maze of Limbale. The village space is segregated on the basis of caste where Bhimnagar is on the periphery of the village. When the Mahars decide to convert en mass into Buddhism, a foreign religion, so that it cannot be appropriated by the Hindus, the upper caste Hindus feel threatened. "The fear is not about damaging the Hindu religion but about treating Mahars equally"(113). Thus conversion offers an opportunity for the converts to be treated equally by others which threatens the preexisting order. But whatever religion they adopt, they still will be living in Maharwad, a space that is endowed with Dalit identity. Thereby indicating how spaces also constitute an identity for the individuals that inhabit it. 
The bus where Surekha Mane is asked to "sit properly", the road where first Tatya Kamble is murdered and later Prabhakar Kamble is murdered by Kabir Kamble, the bara acts as a boundary of the house that must not be transgressed and once Sonali crosses it in the night to meet Rohit, her dignity is lost, the farmhouse which acts as a private space where Gopichand and Manikchand's real identity reveals itself as they rape a woman, who perchance happens to be a Dalit, or the rooftop through which Sonali witnesses the culture of Mahars, the murder of Tatya Kamble as well as realises Rohit's love for her. Her desire for Rohit makes her want to "sell her body"(83) while standing on the rooftop. It then provides a space which helps her exist outside of the confinements of patriarchy, caste and marriage.

Sudhakar Kavale occupies a third space within the house of Rambhau Kavale. His madness or psychological illness is used to portray a very gory, grey and dark humoured side of the novel. When he asks if Surekha Mane will marry him, she replies, "How much dowry will you take?"(66) Sudhakar's adornment of Prabhakar's blood stained clothes, his will to get intimate with Sonali are disturbing images. Sudhakar is a mirror that Limbale holds in front of the society, merely presenting to them the chaotic madness that it represents which is termed insane, shunned by most and needs to be controlled or silenced most of the times because of both his mind as well as his body.

While travelling in the bus, Kasbe Guruji first sits with Godbole Guruji and after he gets down, Surekha Mane who is a Dalit sits alongside him. For him it is only because of untouchability being abolished in public places that Mane or Godbole Guruji can sit alongside him. But the psychological divide becomes visible when he asks Surekha Mane to "sit properly" (37) as her body keeps touching him. This 'touch' or corporeality as a discourse is explored by Limbale through multiple facets. It can be seen in the lascivious eyes of Milind Kamble that gaze at many women throughout the novel and when he finally tries to touch Shaila Satpute, Milind turns into a eunuch. Vishnu Pandit's lust for Draupadi makes 
him transgress both his religious as well as his caste duties as he takes her by the hand inside the temple but Draupadi saves herself by scratching his hand. Later when Vishnu Pandit makes Sadashiv More believe that Draupadi is the one who is doing 'jaadu-tona' on his sister, she is paraded naked in the village which strips her off not only her clothes but also her human rights and dignity. Mahasweta Debi in her short story 'Dopdi' also refers to a tribal woman being raped by many policemen. As soon as she strips herself off, her naked body turns into a sight to be feared. Here, Draupadi's body becomes a sight to be devoured because she too has internalised the male gaze. When the dilapidated and burnt houses in Bhimnagar are replaced by new houses built by the government. The sweets distributed by Mahars which are thrown away "in the garbage heap"(80) indicating the psychological barriers which label Dalits as 'polluted'. When Milind is given mutton to eat, he envisions of eating Tatya's corpse, a crude metamorphosis of the body.

The corporeality is again presented through Rohit Kamble and Sonali's dance which causes uneasiness in Sonali's father. Their relationship is built on longing for each other's touch. In opposition to this is the rape of the Dalit woman by Gopichand and Manikchand in their farmhouse.

When Sonali transgresses the bara to meet Rohit Kamble, she is reprimanded by her father-in-law. Rambhau and Shripatrao discuss Sonali's fate by saying it would be dangerous to throw her out only because she could go against Prabhakar or it will seem as they did not take care of Sonali and it would be difficult to get their son remarried after he returns from prison and also because they need someone to do the household chores. The physical labour which is passed on to women or to the Mahars brings to the fore another subjection that has been prevalent. Why is the labour intensive work given to these already subjected and vulnerable sections of the society and then seen as inferior to mental work or spiritual work. The discrimination faced by Sonali finds voice when Parvatibai questions Rambhao, "It is 
fine by you when your son commits a crime. Why shouldn't it be so if this girl commits a crime?"(86) The solidarity of the women inside the bara is an exemplar for women portrayed outside it that are seen disparate and individually catering to their families. This reversal by Limbale helps us dismantle the stereotype of Dalits as standing unified against the upper caste. There is a humanisation of each character and the novel sketches the graph of many of these to help us garner a broader and yet an extremely nuanced perspective of the village of Achalpur or of how caste functions.

When Milind is unable to get Sitaphale transferred, he says, "Return my money or let me sleep with your wife" (16). This highlights the oppression women face by being doubly marginalised but also that men think of having a right over women, where they take decisions for the women they are associated with. Milind is concerned about what Tatya Kamble's wife would be going through after his murder.

Hema Pandit's name is withdrawn from the nomination of a sarpanch only because she is a widow. Gopichand and Manikchand drag a Dalit woman from the fields and rape her. The Dalit woman they capture is a doe caught in "the tiger's jaws" (20). Milind calls them "demons" but while going to the farmhouse he too looks at a woman, wants to flirt with her and calls her "saali! She is so sexy." (9) He even calls a woman "this lovely dish"(90) as if she is a thing to be devoured. He later claims, "Woman, thy name means fun"(92). But he asks the twins to not rape the woman as she is a Dalit. Thus this 'Othering' based on caste leaves out the atrocities that women have to suffer at the hands of patriarchy. The twins comment that they would not have spared the Dalit woman even if she was from their own caste. They question, "why do you see caste everywhere, even in sex?” (20) We need to question if Dalit see caste everywhere and if they identify gender as an overlapping discourse and not subsumed within caste? What is an identity of a man like Milind or Tatya Kamble? Is it limited to their caste identity as a Dalit or is it more than that? 
Milind says that when water turns into nectar when touched by a Brahmin but it turns into "menstrual discharge" when touched by a Mahar thereby stating menstrual discharge to be impure like the touch of a Mahar. Limbale cleverly brings to the fore the deep seated psychological beliefs that humans carry within themselves due to ages of appropriation and interpellation. When Lakshmi gives birth to a girl, Milind is disappointed though he provides a long narrative of the skewed sex ratio which would lead to more crimes against women. Limbale provides social commentary to the reader through a character who himself is flawed. He is far from the ideal Tatya Kamble. He works to earn instead of constantly working for the movement, he befriends Gopichand and Manikchand, he is unfaithful to his wife, and he is fearful of standing up for his community and is neutered in the end of the novel. The novel then offers a circularity where it ends on the journey without the car reaching its destination, much like the Dalit movement but Milind becomes "impotent" because of his separation from the movement. He has sold himself as the novel ends with him "kissing [Manikchand's hand] loyally"(155).

Tatya Kamble's ghost is a metaphor employed by Limbale to represent the spirit of the Movement or what Dalit consciousness stands for. It smirks at Milind, laughs at his inability to stand for his own caste and urges him to fight against oppression of any kind. It can be compared to the ghost in Shakespeare's Hamlet where his father's ghost urges Hamlet to act morally. Tatya's ghost too haunts Milind but like Hamlet, he too is caught in inaction due to lack of a strong will, thinking 'To revolt or not to revolt'. Madhukar Kamble is terrified of Tatya's ghost entering the bara. Immediately after this he has a dream of being caught by the policemen of his pretension of treating the Dalits equally. The occurrence of the dream just after the fear of Tatya's ghost entering the bara has stirred him which hints at his aversion to being exposed for his hypocrisy once the ghost which is symbolic of the Dalit movement brings Casteism to the fore. 
We need to ask ourselves who is the protagonist of Limbale's Hindu: A Novel? Is it Tatya, his ghost, Milind, Rohit, Kabir, Sonali, Sadanand, all of them or none of them? Is Limbale himself the omniscient protagonist? Is there a need for a protagonist is what Limbale questions through this text. Is there a need for an ideal hero to lead the movement and end caste, is it possible? Or is there a need to understand that as caste evolves, so do humans, and as they move towards their neutered selves, the fabric of caste loses its hold at some places but gets knitted strongly at others.

For Milind, “[people] from different castes could live happily together if they tied up all controversial issues in a bundle and put it aside"(118). But this would be negation of caste. The only thing we know for certain is that "The injustices and atrocities perpetrated upon dalits have many dimensions." (Limbale $\mathrm{x}$ ) Limbale claims, "Let every blind person read this text and find implied meanings according to his or her own blindness" (Limbale $\mathrm{x}$ ). This novel seamlessly draws connections, friendships, relationships and enmities amongst its characters. Limbale is adamant to break every bara, every boundary and every division that the reader might expect. The neutering of many characters in the novel is the reality of Achalpur but "[a] movement does not run on the strength of people with fickle loyalties. A movement goes forward only on the shoulders of people who have stamina and faith"(132) and this movement is then driven as much by Babasaheb Ambedkar as by Tatya's ghost in Achalpur. The question Limbale leaves the reader with is can no living man carry the movement forward to its destination of eradicating caste hierarchies? Does he have to lose his life or be neutered by the societal pressures? Is there a destination at the end of this movement or is it being driven by people like Gopichand and Manikchand who drive it like their car which is representative of debauchery, gluttony and lust and moving towards suppressing the Dalit consciousness. 


\section{Works Cited}

Limbale, Sharankumar. Hindu: A Novel. Translated by Arun Prabha Mukherjee. Samya, 2010.

Limbale, Sharankumar. Towards the Aesthetics of Dalit literature: History, Controversies and considerations. Orient Black Swan, 2004.

Saranya, U.S. "Portraying the Religious and Caste Discrimination: A Critical Study of Sharankumar Limbale's novel Hindu". International Journal of Research in Social Sciences. 7,12,2017. pp. 86-92.

http://www.ijmra.us/project\%20doc/2017/IJRSS_DECEMBER2017/IJMRA-

12791.pdf 